International Journal of

MULTILINGUAL

EDUCATION

\section{MULTILINGUAL EDUCATION}

ISSN: (Print) ISSN 1987-9601

(Online) E ISSN 1512-3146

Journal homepage: http://multilingualeducation.org/

\title{
From The Panther Skin to the Translations of the Holy Books by Georgian Jews - Linguistic Parallels
}

\author{
Reuven Enoch (Ruben Enukashvili) \\ The Institute for Research of Jewish \\ Communities of the Caucasus and the \\ Central Asia \\ Professor at Ariel University \\ Email: reuvene@ariel.ac.il
}

To cite this article: Reuven Enoch (2021), From The Panther Skin to theTranslations of the Holy Books by Georgian Jews - Linguistic Parallels:

International Journal of Multilingual Education, \#19; pp. 1-7.

DOI: $10.22333 /$ ijme.2021.19001

To link to this article: https://doi.org/10.22333/ijme.2021.19001 


\title{
Reuven Enoch (Ruben Enukashvili)
}

Ariel University, Israel

\section{From The Panther Skin to the Translations of the Holy Books by Georgian Jews - Linguistic Parallels}

\begin{abstract}
In the present paper, we will discuss some of the linguistic parallels that exist between the panther and these translations. Of course, such parallels can be inferred if the above assumption about the timing of the translation is correct and, on the other hand, given the immeasurable impact both of these monuments had on their readers. We will touch on some interesting linguistic parallels that emerge when comparing texts.

Keywords: Vocabulary; translation, Georgian-Jewish linguistic relations; linguistic parallels
\end{abstract}

For centuries, Georgian Jews have preserved translations of the holy books and some other fundamental religious books, translated into their vernacular and known as "Tavsili" (translation, commentary). For the last ten to fifteen years, little was known about these translations in scientific circles. In 2008, a translation of the book of Genesis was published in Israel (Genesis, 2008) in three different editions, followed by an extensive study of the text a year later, and in 2014 a translation of the Passover Legend (the Feast of Tabernacles) was released to the public (Feast of Tabernacles, 2014). These translations were passed down from generation to generation orally among Georgian Jews. The spiritual leaders of the community have been teaching them for years (there were also special terms - „os 3 bom 8 J $\$ 8 S^{\text {“ }}$ - "stand on the head"). Nowadays, when the vast majority of Georgian Jews live in Israel, the area of use of these translations is significantly reduced. Their fragments are mainly used in the preaching of the so-called "Dibra Torah" ("Torah is said"). There is no direct document as to the time of the creation of the translations. According to indirect data, this date is estimated to be the 11th- 12th C. (Enoch, 2009, p. 8). One of the proofs is the language of translation, which is close to the language of Georgian secular monuments of that time. The beauty of Rustaveli's eloquence (Glonti 1961; Gigineishvili, 1975) has been studied in 
detail in scientific literature, including the peculiarities of the great poet's pronunciation of names.

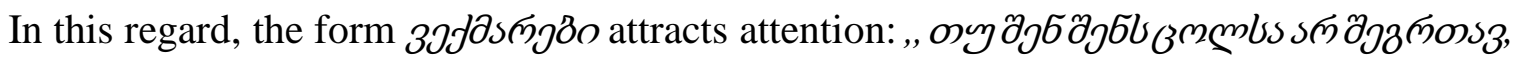

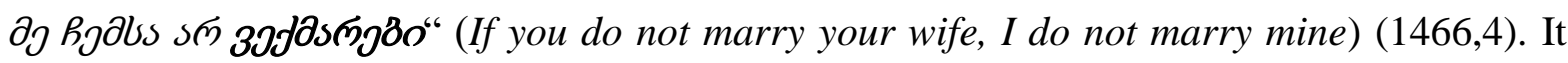
seems that this verb existed in Georgian at that time (or in any of its dialects) and Rustaveli used it so gracefully in the poem. The fact is that in the original text of Genesis, we find the

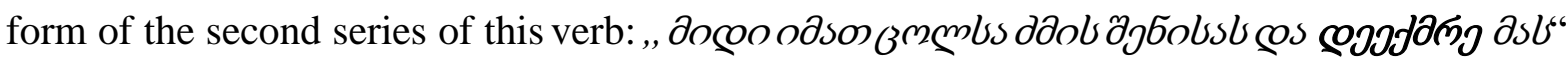
(Marry your brother's wife). In the modern translation of the Bible, we have the equivalent of it. Also in Shalom David's translation: $\partial d \partial$ ’

A different edition is presented in the translation of Abram Mamistvalov, Tamar Mamistvalov-Kezerashvili, and Gershon Ben-Oren, where other lexical items are used:

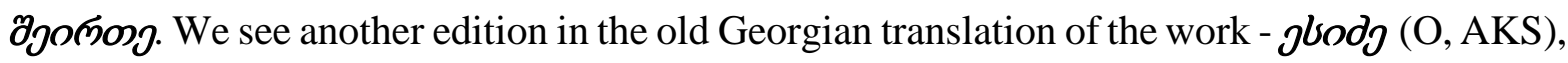
cosjlodg (CV). All these clearly indicate the diversity of Georgian vocabulary and to the fact that translators were not entirely sure which word would be more appropriate for the translated text. It is noteworthy that in both the text - in the panther skin and in the chapter we have the initial form of this verb:

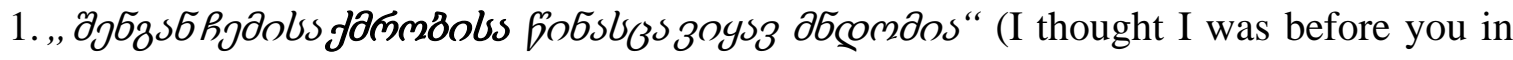
my manhood);

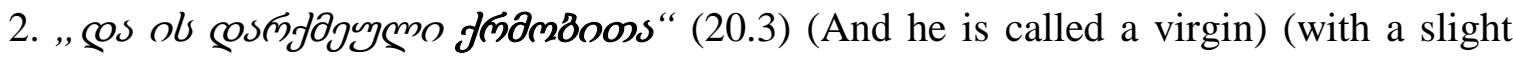
phonetic change), which literally means: because he is married. This is clearly seen in the old

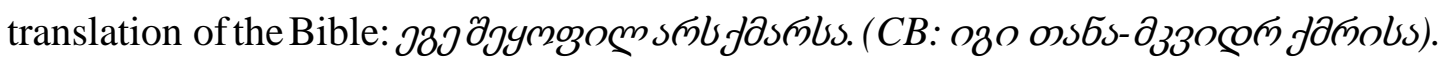

This form is discussed by Shalva Glonti, who thinks that it, like a number of other verbs, must have been coined by Rustaveli. Of course, no one doubts the unique mastery of the great poet, but in this case, Ivane Gigineishvili's view that Rustaveli was well acquainted with the possibilities of the Georgian language and skillfully used the existing forms should be more correct. In our humble opinion, the fact that these forms can be found in Tavsili, which should have been created slightly earlier than the genius poem, backs up Ivane Gigineishvili's opinion (GigineiSvili, 1975, ; Ben-Oren, 1993). However, it should be emphasized that we are not discussing the case of influence here, but merely highlight that both Rustaveli and the anonymous creator of Tavsili use existing forms from the rich source of the Georgian language (Enoch, 2009). 
Both texts also confirm the 6yz235 form, which is explained as follows: "request,

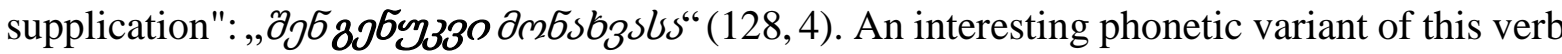
is presented in the chapter: $80^{6} \boldsymbol{y} 3 \jmath^{80} 0$, which means

"I beg you". We must repeat that the use of such forms indicates their existence in the Georgian language.

One of the forms used in Panther's skin needs careful consideration, as it can be understood in a different way from the traditional definition. We have in mind the verb зुलssms

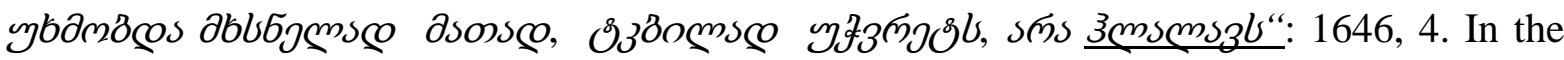
dictionary attached to the edition, this word is defined as:" does not quarrel." As it is known, Rustaveli's masterpiece was translated into Hebrew by Boris Gaponov (Gaponov, 1991) and this translation is recognized as congenial. It should be noted that in this case the translator does not follow the above definition and offers a different understanding: ומענה "ותקרא להם "ישענו במשאל Translating this back to Georgian, we have the following situation: the primary meaning of משאל is ,bלm36s“ (memory); the word מענה has essentially the same meaning, but it has a secondary meaning as well "plan or action that gives a solution". We should roughly understand the translation like this: pays enough attention (does not show lack of attention). It is difficult to say with certainty which understanding is more acceptable, but in our view, Rustaveli's researchers should also look to the Gaponovian understanding. We have an interesting word in one of the most beautiful stanzas of the Panther's skin, which is still used in

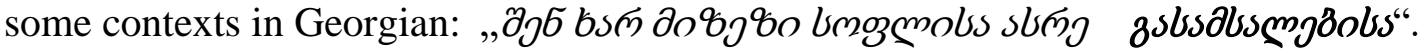

According to the definition, this word is related to "bsalssms" and is explained as

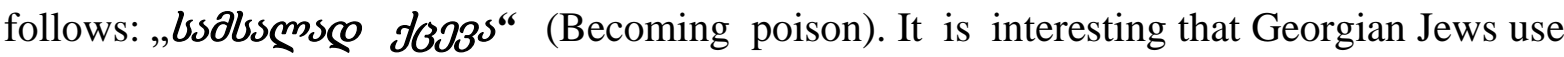
even today, the modified version of this word: "zsbs6lssmgzs" (for example, in the materials

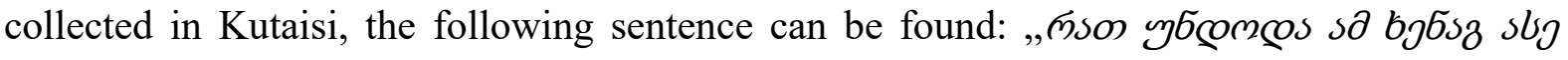
zsus6lscmg8s" (Who and why made this Khenag dish (popular dish among Georgian Jews, made of wings and walnuts) so spicy/billet?. Of course, the meanings are very close, but for the sake of clarity, we point out that greed here means "bitterness" and maybe Rustaveli also had this meaning in mind.

Particular attention is paid to the form „bsbo“, which is confirmed several times in Rustaveli's poem with two different meanings:

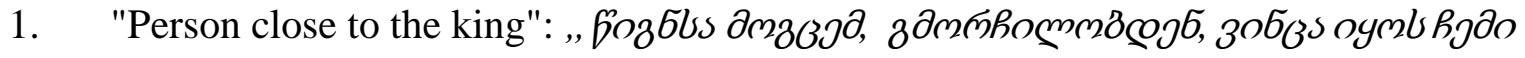


bsbo" $(164,4)$;

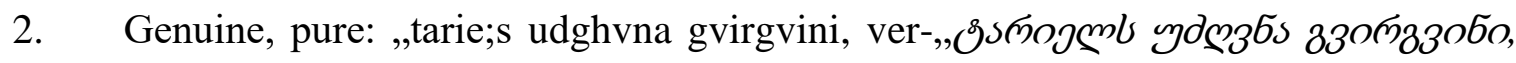

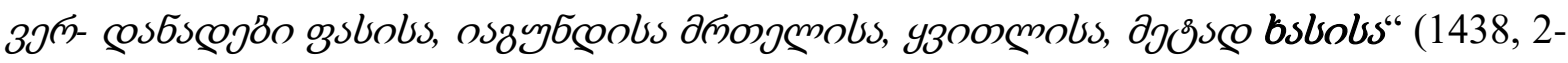
3). The word bsbois often found in the speech of Georgian Jews, and according to this we could add other meanings - "true", "saint of saints". This can be clearly seen from the short verse that

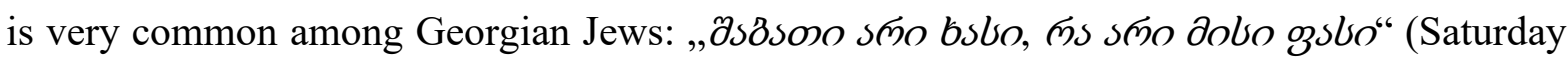
is a "khasi", it is priceless). The words cossbsbjal, cossbsujoobjal, bslejos, (characterizes) are derived from bsbo. The translation of Tavsili uses this very phrase:

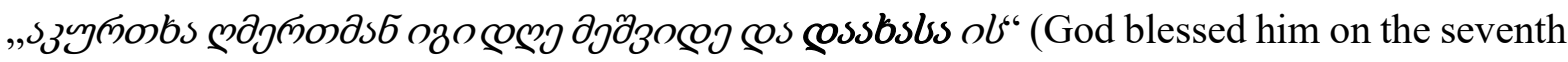
day and made him a saint): ( $\jmath 6 \jmath \iota \circ \downarrow, 2008,2-3)$. In one of the previous works I expressed an opinion that the word on was used as "saint" in the speech of Georgian Jews (Enouch, 2009, p. 87). Thus, we can conclude that lexical items of approximately similar meaning were developing in parallel in the speech of Georgian Jews and in the Georgian literary language.

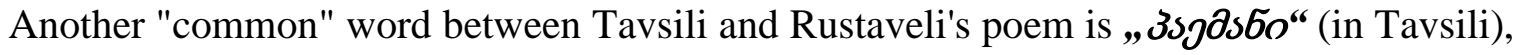

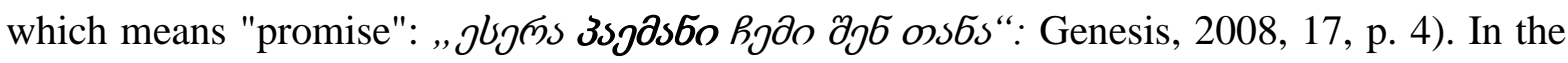
section 17,2-13, this lexical unit has been used several times. Sometimes the speaker left him unchanged, but in most cases he said "3ంmm8s" instead. So for him these units are absolutely identical. The publishers of Panther's skin define the word "paemani" as agreement, pact, deadline. I think it should be clear that this lexical unit is used smoothly by both texts. Discussing any influence here does not seem justified. It is interesting in itself that Tavsil has preserved this archaic form.

In some cases, it is not so easy to bring the form confirmed in the translation of the poetic unit and the chapter to the "common meaning". For example, one of the most interesting forms

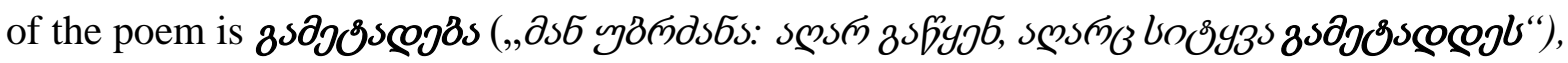
, which is defined as: "more behavior, exaggeration." The lexical unit attested in the chapter

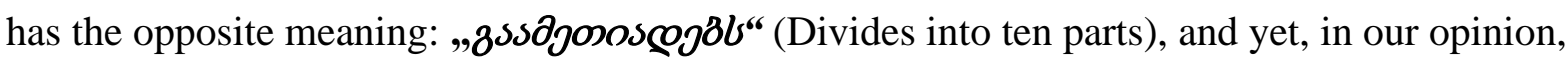
it is not impossible to judge the common origin of these units not only because of external similarities but also as a result of the so-called meaning in one text, replace with the opposite meaning.

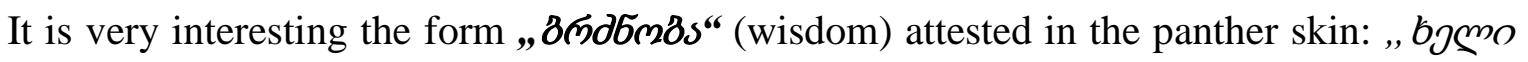




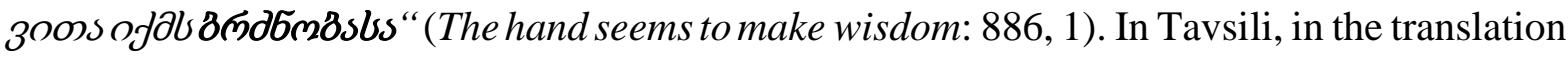
of Agad, we find a new word derived from this verb:

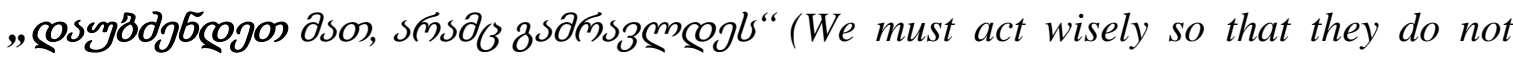
multiply)... These examples once again show the great potential of Georgian vocabulary, which is used with true mastery by both the genius poet and the most talented translators of the Tavsili.

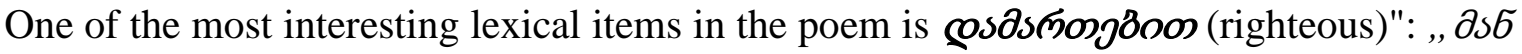

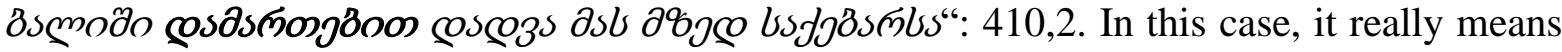
"beyond", but there is no doubt that we are dealing with the same lexical unit. It is noteworthy that neither Ilia Abuladze (Abuladze, 1973) nor Zurab Sarjveladze's (Sarjveladze, 1995) old Georgian dictionaries have confirmed this lexical unit. With great caution, perhaps, we can say that it must have been the product of the time of the creation of the „Tavsili“ and „The Panther Skin“.

The word 6sbo, which means "ugly, ugly", is often used in panther skin. It is a well-known

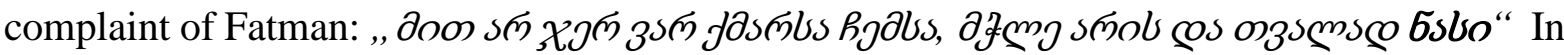
the speech of Georgian Jews, a slightly modified phonetic version of this word is used: 6s凸̋o. R sound development is a completely normal process in georgian; But In none of the translations of the Tavsili is this word found without the consonant $r$. The poem also confirms

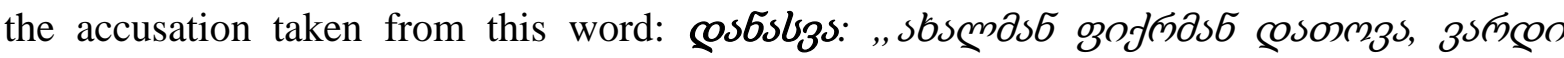
cosonnomons, cosbsts" 179,1), the explanation of which is "to become". Gaponov's (Gaponov, 1991) translation - הקפיא ויבל - sound and freeze, which indicates a different understanding of the text and offers a different meaning of the word.

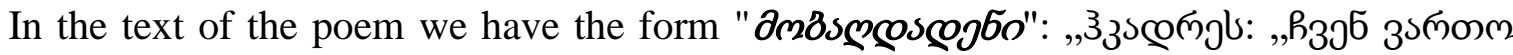

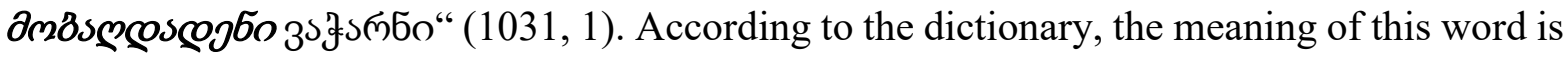
"Baghdadi ". Gaponov's translation is as follows: מבגדד העיר אתינו. With the translation: "We are coming from Baghdad". It is noteworthy that there is a similar form in the speech of

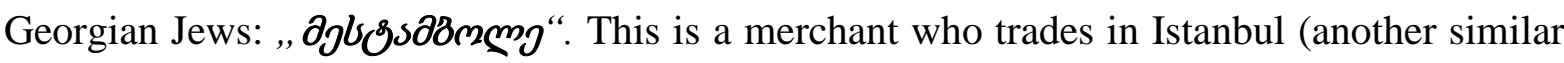
form is „дgny „2mbsलs Baghdad anyway. 
Every Georgian remembers the Rustaveli stanza from his childhood: „, bsosjool dymog6o

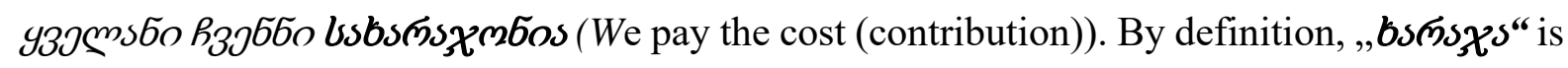
a contribution. It seems that in Georgian there was a term not only to denote a contributor, but also a tribute. This is evidenced by the testimony of the „Tavsili“: In A edition of the

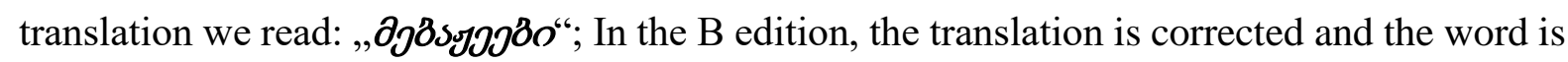

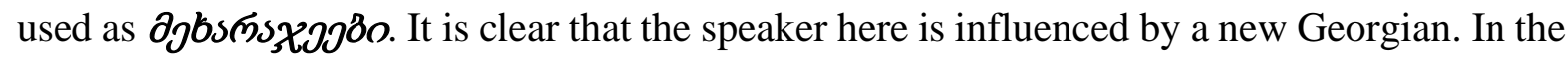
text of the 60s of the twentieth century, but in the text preserved by oral tradition, a completely re-Georgianized form appears: "supervisors of works". Of course, it is especially valuable for us to show the A and B editions, according to which we are talking about tax collectors. So, we can present the specification regarding the lexical item under consideration.

In some cases, with the parallel forms of „Panther Skin“ and „Tavsili“, we can also discuss the possible time for certain words to enter the Georgian language. For example, the poem

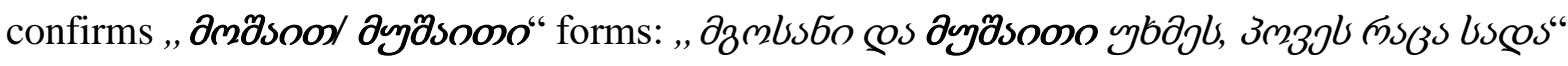

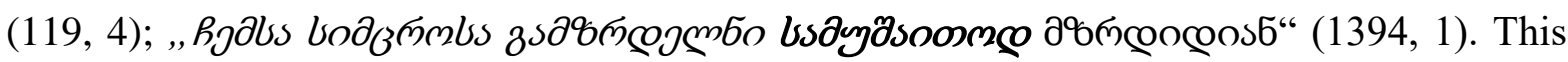
lexical unit is not found in the passages published by the translation of the chapter, but is in the texts provided by the speakers. For example, Mrs. Eter Kezerashvili-Chikvashvili suggested a sentence from the speech of the Jews of Akhaltsikhe: „2ygzoon 308m6jzs“"This form is no longer found in the speech of the Jews today, and we may assume that it is a reminder of earlier eras.

We are sure that after publishing the rest of the chapter and comparing the texts, many more interesting materials will be revealed. 


\section{References}

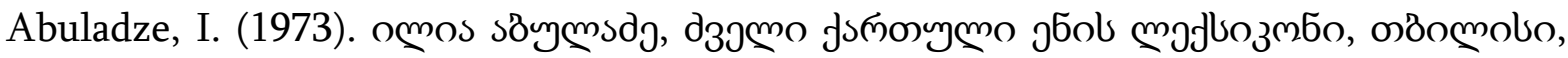
дэзбол๓

Ben-Woren, (1993). תכונות מיוחדות של שפת-הדיבור של יהודי גאורגיה, עבודת דוקטורט, האוניברסיטה , העברית בירושליםEnoch R. (2009). The Study of Tavsili According to the Book of Genesis, Jerusalem, Magnes,

Feast of Tabernacles, (2014). Five Year Calendarof Jewish Holidays, 2014-2018.

Gaponov, B. (1991). The Man in the Panther's Skin (in hebrew), Publisher Israe, London. Genesis, (2008). Reuven Enoch, The Traditional oral Translation of the Bible in JudeoGeorgian. A Critical Edition ofGenesis.Part I. The Text. Jerusalem, Magnes, 2008.

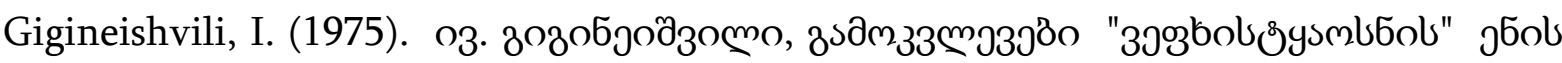

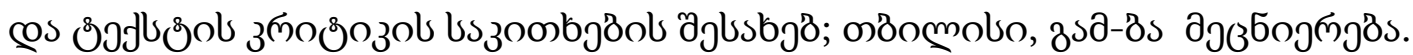

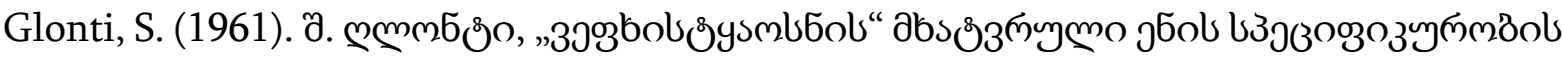

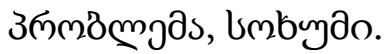

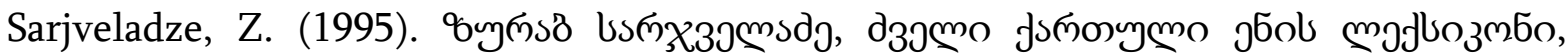

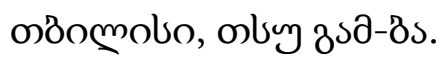

